\title{
Involvement of Corticotropin- Releasing Factor and Receptors in Immune Cells in Irritable Bowel Syndrome
}

\author{
Mahanand Chatoo', Yi Li ${ }^{1}$, Zhiqiang Ma', John Coote ${ }^{2}$, Jizeng $\mathrm{Du}^{1,3,4}$ and Xuequn Chen ${ }^{1,3,4 *}$ \\ 'Division of Neurobiology and Physiology, Department of Basic Medical Sciences, School of Medicine, Zhejiang University, \\ Hangzhou, China, ${ }^{2}$ School of Clinical and Experimental Medicine, University of Birmingham, Birmingham, United Kingdom, \\ ${ }^{3}$ Key Laboratory of Medical Neurobiology of the Ministry of Health, Institute of Neuroscience, School of Medicine, Zhejiang \\ University, Hangzhou, China, ${ }^{4}$ Key Laboratory of Medical Neurobiology of Zhejiang Province, Institute of Neuroscience, \\ School of Medicine, Zhejiang University, Hangzhou, China
}

OPEN ACCESS

Edited by: Yong ZHU, East Carolina University, United States

Reviewed by: Kazuhiro Kamada, Kyoto Prefectural University of

Medicine, Japan

Xiaohua Hou,

Wuhan Union Hospital, China

*Correspondence: Xuequn Chen chewyg@zju.edu.cn

Specialty section: This article was submitted to Experimental Endocrinology, a section of the journal

Frontiers in Endocrinology

Received: 29 November 2017 Accepted: 18 January 2018

Published: 12 February 2018

Citation:

Chatoo M, Li Y, Ma Z, Coote J, Du J and Chen $X$ (2018) Involvement of

Corticotropin-Releasing Factor and Receptors in Immune Cells in Irritable Bowel Syndrome.

Front. Endocrinol. 9:21. doi: 10.3389/fendo.2018.00021
Irritable bowel syndrome (IBS) is a common functional gastrointestinal disorder defined by ROME IV criteria as pain in the lower abdominal region, which is associated with altered bowel habit or defecation. The underlying mechanism of IBS is not completely understood. IBS seems to be a product of interactions between various factors with genetics, dietary/intestinal microbiota, low-grade inflammation, and stress playing a key role in the pathogenesis of this disease. The crosstalk between the immune system and stress in IBS mechanism is increasingly recognized. Corticotropin-releasing factor (CRF), a major mediator in the stress response, is involved in altered function in Gl, including inflammatory processes, colonic transit time, contractile activity, defecation pattern, pain threshold, mucosal secretory function, and barrier functions. This mini review focuses on the recently establish local Gl-CRF system, its involvement in modulating the immune response in IBS, and summarizes current IBS animal models and mapping of CRF, CRFR1, and CRFR2 expression in colon tissues. CRF and receptors might be a key molecule involving the immune and movement function via brain-gut axis in IBS.

Keywords: corticotropin-releasing factor, CRFR1, CRFR2, inflammation, irritable bowel syndrome

\section{INTRODUCTION}

Functional gastrointestinal disorders (FGIDs) are a group of idiopathic disorders which affect different parts of the gastrointestinal (GI) tract. They are classified by GI symptoms related to any combination of the following: motility disturbance, visceral hypersensitivity, altered mucosal and immune function, altered gut microbiota, and altered central nervous system (CNS) processing. The FGIDs are classified into six major domains for adults including irritable bowel syndrome (IBS) which is in FGIDs-C. IBS is defined by ROME IV criteria as pain in the lower abdominal region, which is associated with altered bowel habit or defecation $(1,2)$. Patients are diagnosed according to symptom-based criteria and the majority of the time they report recurring pain in the lower abdomen, accompanied by altered stool form or frequency $(2,3)$. These symptoms occur without any known structural abnormalities $(3,4)$. IBS is further subcategorized as diarrhea predominant (IBS-D), constipation predominant (IBS-C), alternating (IBS-A), or unspecified (IBS-U) $(1,2)$. The global prevalence of IBS is $11.2 \%$ making it an important clinical entity, but the underlying mechanism is not fully understood (5). 


\section{POSSIBLE CAUSES OF IBS}

Irritable bowel syndrome is a multifactorial disorder with diet/ luminal microbiota, low-grade inflammation, stress, and genetics. IBS patients report a worsening of symptoms after eating specific food such as diary product, hot spices, and wheat product. Recent area of interest relates the effect of altered intestinal bacterial flora namely increased Firmicutes and reduced Bacteroidetes, Lactobacillus, Bifdobacteriumsp, and Bifidobacter to the onset IBS $(1,6)$. There is evidence that the luminal microbiota affects GI motility by interacting with muscularis macrophage and enteric neurons (7). In a prospective trial, IBS patients receiving Bifidobacteriumlongum showed decreased-depression scores, improved quality of life scores, and overall symptoms (8). Investigators have also suggested that small-intestinal bacterial overgrowth might contribute to IBS progression (9).

There is evidence to support the role of mild intestinal inflammation in the etiology of IBS. Researchers have found alteration in inflammatory mediators in the GI tract as well as in the peripheral blood circulation of animal and patient with IBS. Patients reported the onset of postinfectious IBS, a subset of IBS, after contracting viral, bacterial, protozoa, and nematode infections $(6,9)$. There are experimental models showing that inflammation, even if mild, could lead to long-term changes in GI nerve and smooth muscle function, resulting in dysmotility, hypersensitivity $(1,7,9,10)$.

ROME IV uses a biopsychosocial conceptual model to explain the susceptibility to develop IBS. This means that IBS is the product of interactions between various factors and stress (1). Psychological and physical stresses exacerbate GI symptoms. IBS patients also suffer from psychiatric disorders such as anxiety and depression $(9,11)$. Animal and human studies have demonstrated that stress stimulates colonic motor function, reflected by decreased-colonic transit time, increased contractile activity, the induction of defecation, and symptoms of diarrhea. There is also evidence to support that stress affects gut-pain threshold, mucosal secretory function, barrier functions, and visceral inflammatory response $(1,4)$.

Irritable bowel syndrome patients more often have a family history of IBS (1). A search for candidate genes to reinforce the hypothesis that environmental factors play an important role in the pathogenesis of IBS has led to the association of serotonin transporter gene and cholecystokinin A receptor gene with IBS. It has been found that patients with IBS-D have a functional polymorphism in the serotonin transporter gene (6).

\section{CRF MECHANISM IN IBS}

The hypothalamic-pituitary-adrenal (HPA) axis is crucial in maintaining homeostasis and plays an important role in responses of the endocrine system and behavioral activity to various stresses. Corticotropin-releasing factor (CRF or CRH) plays a pivotal and well-established role in activating the HPA axis under basal and stress conditions (12). There is convergent evidence indicating the presence of CRF, Ucns, CRFR1, and CRFR2 in various peripheral tissues such as GI tract, heart, lungs, spleen, testis and adipose tissue, and CNS. CRF, Ucns, and CRF receptors have been identified in myenteric neuron, sensory nerve, sympathetic nerve, enterochromaffin cell, and immune cells in the intestine of animals and human. This indicates that both central and peripheral CRF systems modulate the body response to stress and modulate syndromes that occurs in IBS (11-14). Early weaning stress in pigs (15-21 days) causes impaired intestinal mucosal function. A decreased-CRF protein, an increased-CRFR2 protein, and no change in CRFR1 protein was detected in jejunum of late weaned pigs. Blocking both CRFR1 and CRFR2 improved disturbances in barrier function, whereas blocking CRFR2 leads to an enhanced barrier dysfunction, showing that dysfunction and hypersecretion is mediated by CRFR1 (15). Central administration of CRF induced colonic hypersensitivity in low-anxiety rats (Fischer 344); this effect was inhibited by pretreatment with CRFR1 antagonist (16). Water-avoidance stress and injection of CRF increased fecal pellet output which is inhibited by CRFR1/R2 antagonist and CRFR1 antagonist CP-154,526 (17). Therefore, CRF via its CRF receptors affects smooth muscle contractility, mucosal permeability, mucosal transport, and visceral pain sensitivity, indicating possible correlation with colonic manifestations of IBS $(4,11,13)$. To study the mechanism of IBS, many animal models have been developed. Various approaches using chemical, mechanical stimulation, and physiological/psychological stress such as drugs, colorectal distention, restraint stress, maternal separation, water-avoidance stress, electric foot shock, and cold water stomach irrigation (18-27) have been used to study IBS pathogenesis on animal but no ideal animal model has been created up till now. Table 1 is a summary of the currently used stresses in IBS model to study its different hallmarks.

\section{INVOLVEMENT OF CRF SIGNALING IN IMMUNE CELLS IN IBS}

Recent studies demonstrated a novel therapeutic potential of the mechanisms showing complex interactions between immune cells, epithelial cells, smooth muscle, enteric nerves (28), as well as their respective roles in manifestations of clinical symptoms of FGIDs (29). IBS was thought to be a neurological condition as a result of imbalances in brain-gut axis, but there has been growing evidence revealing immunological imbalances in IBS patients with a chronic and a low-grade immune activation(3). CRF promotes inflammation by stimulating release of proinflammatory cytokines TNF- $\alpha$, IL-1, IL- 6 , and macrophage inflammatory protein $1 \alpha$ (MIP- $1 \alpha)$ from immune cells in GI $(11,13,30)$. CRF and CRF receptors in the CNS are also key signals triggering various stress response including the altered visceral response in the stomach, small intestine, and colon (11). There is a close anatomic relationship between neurons from peripheral nervous system (PNS) and ENS and resident immune cells $(13,29)$. There is growing and compelling evidence proving the correlation between mild inflammatory response and stress in IBS pathogenesis. But so far not much clarification has been given on the role played by the peripheral CRF-receptor signaling in this inflammatory response (11-14). A variety of 
TABLE 1 | Stress-induced irritable bowel syndrome (IBS) animal model in the current literature.

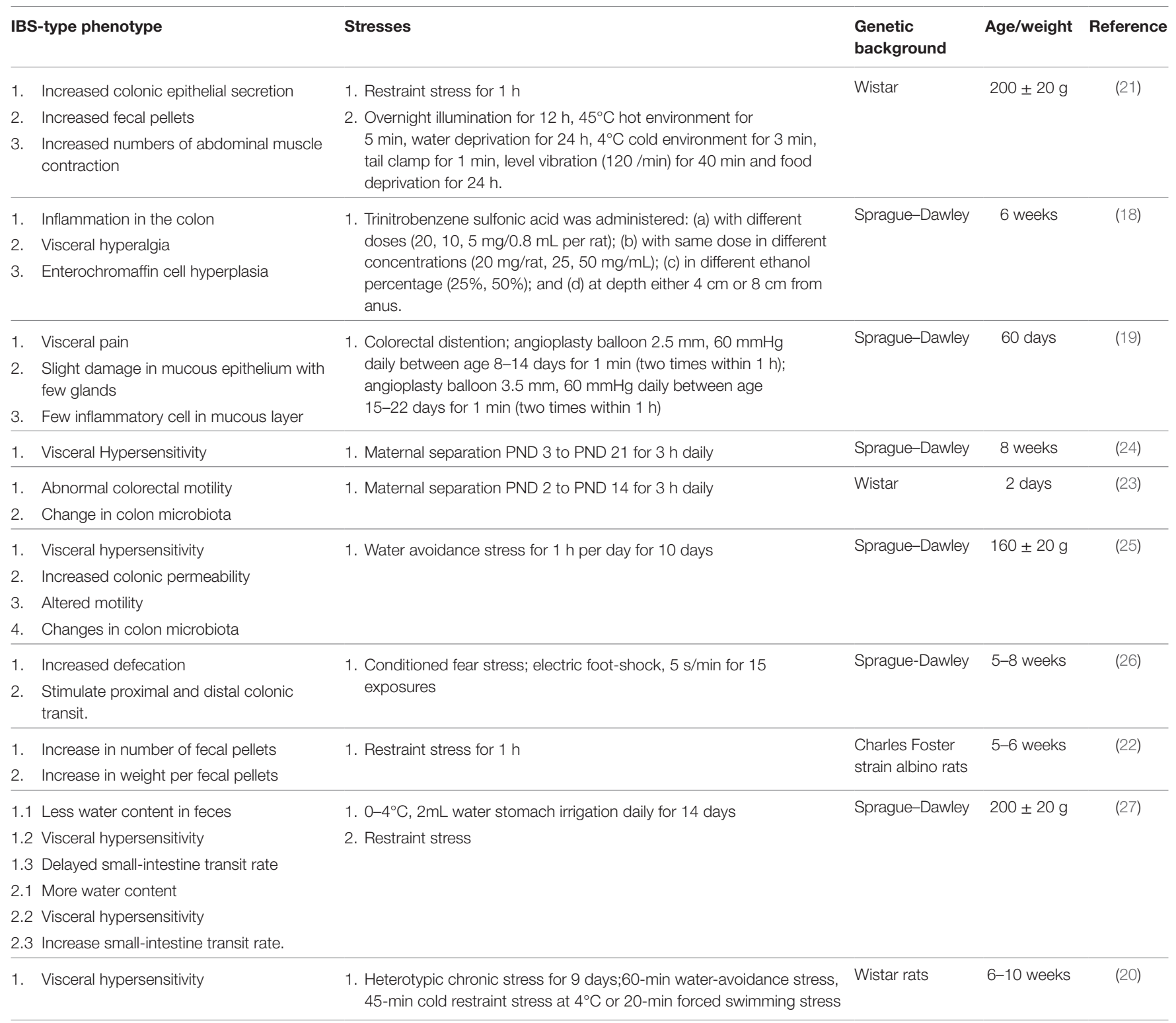

immune cells are involved in the pathogenesis of IBS. Here, we have selected six immune cells, namely intestinal epithelial cells, macrophages, dendritic cell, mast cell, T cell, and B cell to review. CRF, CRFR1 and CRFR2mRNA, and protein have been found in GI tissues such as blood vessel, B cell/plasma cell (31-35), dendritic cell, enterochromaffin cell (30, 36-41), epithelial cell $(39,40,42-44)$, goblet cell (31), intestinal crypt, lamina propria (40, 43), macrophage $(32,35,39,42,45-48)$, mast cell $(49,50)$, myenteric plexus $(31,40,42,50-52)$, stem cell of intestinal crypt (31), submucosal plexus $(31,42,52)$, and T cell $(32-34,53,54)$. Figure 1 is a graphic summary of the expression of CRF, CRFR1, and CRFR2 in GI tissue.

Intestinal epithelial cells protect the body against luminal antigen and pathogens derived from the external environment by producing high amounts of mucus and secreting antimicrobial peptides. Tightly sealed by tight junctions the intestinal epithelial cells allow only small molecules to cross the epithelium via the paracellular route (13). They express pattern recognition receptors such as toll-like receptors (TLR) which triggers tissuespecific innate immunity. Furthermore, these cells have the ability to initiate and amplify the immune response by secreting cytokines and chemokines (29). Immunoreactive CRF and CRFmRNA was detected in mucosal epithelial cells in human and rat $(39,40)$. There was CRFR1 at the base of absorptive surface epithelial cell (42) of sigmoid colon in healthy subjects and CRFR2 was reported in epithelial cell of distal/sigmoid colon biopsy samples (55). Water-avoidance stress or mucosal tissue exposed to CRF causes decreased transepithelial resistance and increased paracellular and transcellular macromolecular, ileal villus epithelium, and follicle-associated epithelium (56) in rat 


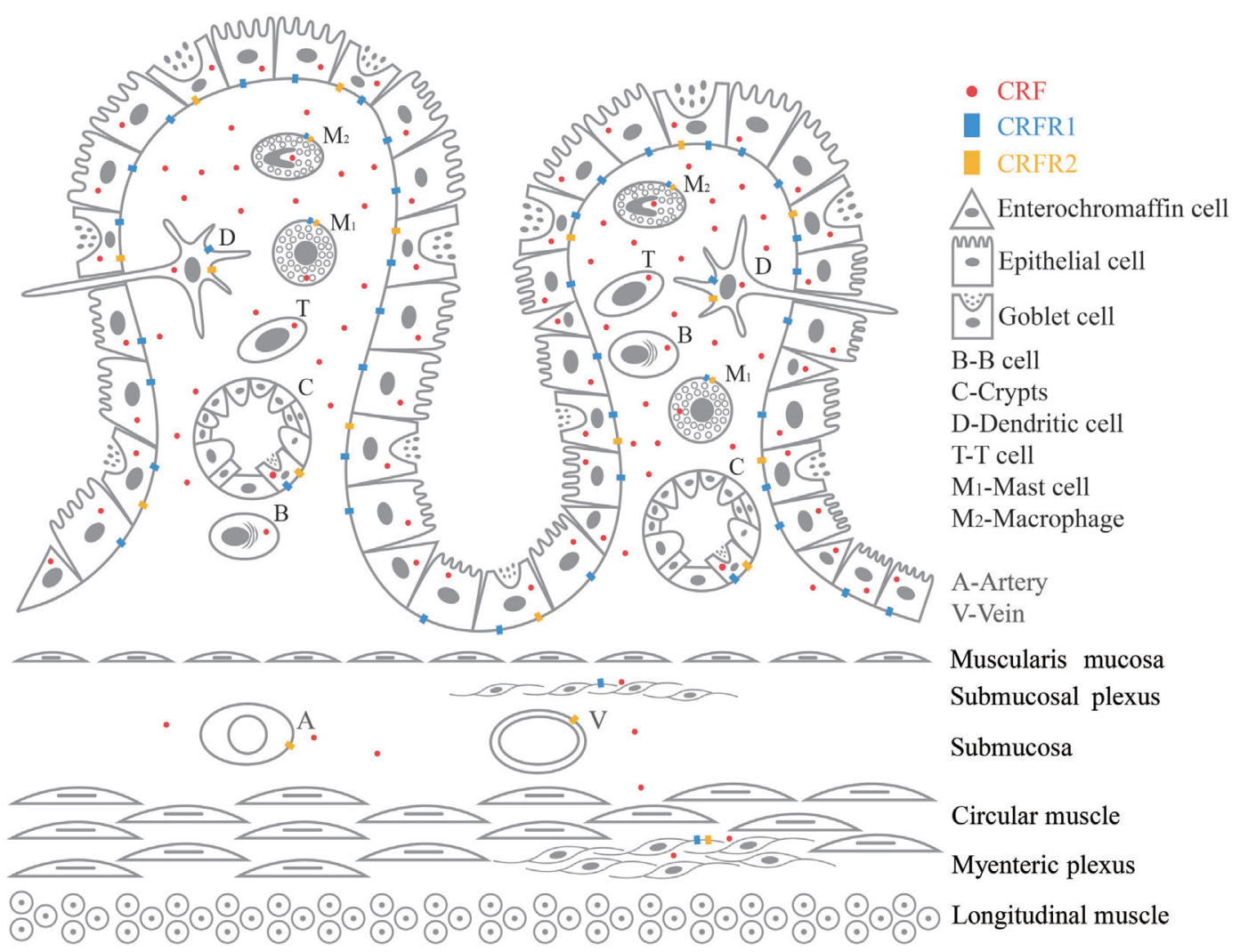

FIGURE 1 | Graphic summary of the expression of CRF, CRFR1, and CRFR2 in Gl tissue.

colon. Also in human colon epithelial cell line (HT-29), CRF decreased transepithelial resistance, increased the permeability of horseradish-peroxidase, increased claudin2, and TLR4 expression at the mRNA and protein level (57). Likewise there is higher expression of CRFR1, CRFR2, TLR2, and TLR4 in peripheral blood of IBS patients, supporting that the activation of CRF-TLR may lead to IBS (58). CRF stimulates ion secretion in the distal colon of Wistar-Kyoto rats in vitro; this epithelial response was inhibited in tissues pretreated with a non-selective CRF-receptor antagonist, indicating the involvement of CRF in ion secretion (59). CRFR2 antagonist delayed healing, decreased epithelial cell proliferation, increased apoptosis, and proinflammatory cytokine expression in colon of colitis mice; meanwhile, there was an increased proliferation and migration in CRFR2overexpressing colonic epithelial cells (60).

Macrophages are innate immune cells distributed throughout the GI tract. The function of macrophages is to maintain tissue homeostasis by phagocytizing and clearing invading pathogens and they also act as antigen-presenting cells and secrete a widerange of cytokines (3). Intestinal epithelial cell-secreted mediators and intestinal luminal content have the capability to stimulate mucosal macrophages (29). Recently, a distinct population of macrophages associated with intestinal muscularis externa has been reported which have the ability to modulate colonic peristaltic activity ( 7 , 29). Macrophages-expressed TRLs, and an increased-TLR4 and
-TLR5 expression, and a decreased-macrophage number have been found in colonic biopsies of IBS. Macrophage-attracting chemokines and number of $\mathrm{CD}^{+} 8^{+}$macrophages are decreased in intestinal biopsies of IBS (3). There is evidence indicating that macrophages have the ability to secrete $\operatorname{CRF}(32,35)$ and the CRF participates in immune system function in inflammation $(39,42,46,47)$. RAW264.7 macrophage cells are positive for CRF, CRFR1 and R2 in immunohistochemistry experiment. CRF can enhance the antigen-specific antibody response through the CRFR1 by NF-kappaB (48). CRFR1 immunoreactivity increased in macrophages in the lamina propria (42) in colonic biopsies with ulcerative colitis. Also, CRF, Ucn1, and Ucn2, via CRFR1 and CRFR2, increase TNF- $\alpha$ transcription in murine RAW264.7 (13). $\mathrm{CRF}$ evoked an enhanced release in proinflammatory cytokines TNF- $\alpha$ and IL- 6 from macrophages in vitro. CRFR1 antagonist reduced the elevated macrophage-derived TNF- $\alpha$, IL- $1 \beta$, and IL-6 in blood after LPS in BALB/c mice (11).

Intestinal dendritic cells shape adaptive immune responses to harmful or infectious intraluminal stimuli through acquisition of luminal antigens and migration to mesenteric lymph nodes to present these antigens to naive T cells. An increased number of intestinal lamina propria dendritic cells, decreased endocytic ability, and enhanced abilities to stimulate $\mathrm{CD} 4^{+}$ $\mathrm{T}$ cell were reported in postinfectious IBS mouse (61). Dendritic cells isolated from mesenteric lymph node of acetic acid and 
restraint stress-IBS rat and cocultured with splenic $\mathrm{CD} 4^{+} / \mathrm{CD}^{+}$ $\mathrm{T}$ cells showed an increase proliferation of $\mathrm{T}$ cells with a rise in secretion of IL-4 and IL-9 (62). Another study, using colorectal distension + restraint stress IBS rat, showed an increase in CD103-positive cells and proinflammatory cytokine IL-4 and IL-9 in colon. Mesenteric lymph node-dendritic cell, cocultured with $\mathrm{CD}^{+}{ }^{+} \mathrm{T}$ cells and $\mathrm{CD} 8^{+} \mathrm{T}$ cells, showed an increase IL-4 expression in $\mathrm{CD}^{+} \mathrm{T}$ cells and increase IL-9 expression in $\mathrm{CD}^{+} \mathrm{T}$ cells. In vitro studies, using JAWSII cells, demonstrated that dendritic cells have the ability to produce and secrete CRF. Commensal bacterial strains can stimulate the production of CRF in dendritic cell, showing that CRF derived from dendritic cell may be involved in the pathogenesis of IBS $(36,37)$. JAWSII cells and mouse mesenteric lymph node-dendritic cells expressed CRFR1 and CRFR2 receptors $(30,38)$. CRF promotes inflammation in mature JAWSII by increasing the production of proinflammatory IL- 6 and MIP- $1 \alpha$ and decreasing antiinflammatory IL-4 (30). CRF increases the capacity of mouse mesenteric lymph node-dendritic cells to stimulate T-cell proliferation, and treatment of mesenteric lymph node-dendritic cells with CRFR1 antagonist yielded a reduced capacity to stimulate T cells (38).

Mast cells are distributed in the mucosa and they have a major role in the transition from innate to adaptive immunity. Activated mast cells release a variety of preformed or newly synthesized inflammatory mediators (including proteases, histamine, prostaglandins, 5-HT, cytokines/chemokines, chymase, CRF, and tryptase) and various factors such as microenvironment, physiological, and psychological stress influenced its phenotype and the release of inflammatory mediators $(29,63)$. Mast cells and neurons in the GI tract express CRF and its receptors $(31,40,42,45,49-52)$ and an electron micrograph from IBS patient colonic mucosa has shown membranemembrane contacts between degranulating mast cell and a nerve fiber, proving the complex integrated interactions between neurons and immune cells via the CRF signaling in the pathophysiology of IBS. Colonic mast cell infiltration and mediator release modulating the intestinal nerve activity have been positively correlated with severity and frequency of abdominal pain in IBS patients (10). Some papers have reported elevated number of mast cell, whereas others have reported an unchanged number of mast cells (3). Investigators have shown the participation of TNF- $\alpha$, a mucosal mast cell mediator, in tight junction dysregulation, and altered intestinal permeability $(13,64)$. In accordance with this finding, the elevated release of tryptase, histamine, and prostaglandin coexisting with increased paracellular permeability have been reported in colonic biopsies of IBS patients (4). Mast cells are immunocytochemically positive for $\mathrm{CRH}$, and RT-PCR data have indicated presence of CRFmRNA in human cord blood-derived cultured mast cells. The presence of CRFR1 and CRFR2 in human and rat colonic mast cells are also supported by functional reports $(13,50)$. Chronic social stress in pigs resulted in reduced transepithelial electrical resistance in the ileum, and increased fluoresce flux in the ileum and colon. This stress also upregulated CRFmRNA in ileum and IL-10mRNA and mast cell chymase gene in both ileum and colon (65).
In distal colon segments in Wistar-Kyoto rat, CRF induced a dose-dependent increase in short-circuit current (ion secretion), enhanced horseradish-peroxidase-flux and release of mast cell protease II. Non-selective CRFR1/R2 antagonist or mast cell stabilizer inhibited these epithelial responses. Mast cell-deficient rats show a reduced epithelial response to stress (59). Mast cell stabilizer alleviates barrier disruption-induced by water-avoidance stress and mucosal tissue exposed to CRF in colon, ileal villus epithelium, and follicle-associated epithelium of rat (56). Restraint stress or CRF administration followed by rectal distention enhanced the number of abdominal cramps and the colonic histamine content. CRF antagonist blocked the stress and CRF-induced enhancement of abdominal cramps (66).

$\mathrm{T}$ cells form part of the adaptive immune system and they are subdivided into different phenotypes including cytotoxic $\left(\mathrm{CD}^{+}\right)$, $\mathrm{T}$ helper $\left(\mathrm{CD}^{+}\right)$, memory $\left(\mathrm{CD}^{+}, \mathrm{CD}^{+}, \mathrm{CD} 45 \mathrm{RO}\right)$, and regulatory $\left(\mathrm{CD} 25^{+}\right)$based upon specific cell markers (29). The immune cells are mainly found in the intestinal mucosa (67). It has been reported that IBS patients have a greater amount of $\mathrm{T}$ cells, which are orienting to the GI tract. Furthermore, there is an increase in activated T cells expressing CD69 and HLA-DR residing in the colon IBS patient. Increased T-cell numbers in IBS patient's biopsies of descending colon correlate with abnormal bowel movement (3). It has also been demonstrated that $\mathrm{T}$ lymphocytes have a major role in mediating changes in neuromuscular function following GI infection (68). Rise in T lymphocyte in Campylobacter enterocolitis patients is positively correlated with gut permeability. This description also matched changes observed in patients suffering from prolonged IBS symptoms after contracting acute bacterial enteritis (63). Convergent evidence indicates that human lymphocytes have the ability to secrete CRF, and CRF participates in immune system regulation by acting locally as a proinflammatory mediator (42). It has been reported that human $\mathrm{T}$ lymphocytes contain immunoreactive CRF (32) and express CRF gene. Stimulation with PHA/TPA leads to an increase in CRHmRNA levels, which decreased after $22 \mathrm{~h}(53)$.

$\mathrm{B}$ cells have a key role in the adaptive immunity as they have the ability to secrete a wide range of antibody, which protects the body against infections. Not only can B cells produce antibody but also act as antigen-presenting cells. IgA made by mucosal B cell is secreted to protect mucosal surfaces and the intestinal tissue against pathogens and food antigens. B cells derived from blood of IBS patients displayed augmented B-cell activation with increased cell surface expression of IgG, CD80, and CD86. UV-light-inactivated probiotic bacteria and LPS-exposed-B cells showed impaired ability to express costimulatory molecule CD80 (69). In IBS patients, immunoglobulin-producing $\mathrm{B}$ cells are involved in low-grade local GI inflammation (3). IBS patients have a lower number of IgA-B cells in the ascending colon and also a decreased number of IgA-B cells (vs. sigmoid colon) (70). Patients with IBS-D display a higher density of germline transcripts (GLTs) and activated B lymphocytes in the jejunal mucosa, which are predominantly distributed along the crypts in the lamina propria. A slight increase in IgA and IgM concentrations in 
the jejunal content was also reported in IBS-D patients (71). There is evidence proving that B lymphocytes have the ability to secrete CRF. In response to hyperthermia, hyperosmolarity and hypoxia stress, human $\mathrm{T}$ and $\mathrm{B}$ lymphocytes secrete CRF which is inhibited by corticosteroids $(32,33)$.

\section{CONCLUSION}

This review summarizes the etiology of the onset of IBS referring to evidence that it may be triggered by diet/luminal microbiota, low-grade inflammation, stress, and genetic composition. Various animal models using chemical, mechanical stimulation, and physiological/psychological stress support that stress affects epithelial secretion, GI motility, inflammatory response, microbiota, abdominal muscle contraction, and response to pain. CRF and CRF receptors are distributed in immune cells, secretory cell, and tissues in the GI tract. Stress via local CRF system can activate cells in the GI tract and this can cause IBS phenotypes such as increase permeability, ion secretion, mucin secretion, visceral hypersensitivity, and release of proinflammatory cytokines. T cells and B cells have been shown to contribute to IBS progression. Further studies on mechanism network of central CRF system (circulation, sympathetic, parasympathetic neurons) and the local GI CRF system will provide new insights in understanding brain-gut axis.

\section{REFERENCES}

1. Drossman DA. Functional gastrointestinal disorders: history, pathophysiology, clinical features and Rome IV. Gastroenterology (2016) 150(6):12621279e2. doi:10.1053/j.gastro.2016.02.032

2. Mearin F, Lacy BE, Chang L, Chey WD, Lembo AJ, Simren M, et al. Bowel disorders. Gastroenterology (2016) 150(6):1393-407. doi:10.1053/j. gastro.2016.02.031

3. Hughes PA, Zola H, Penttila IA, Blackshaw LA, Andrews JM, Krumbiegel D. Immune activation in irritable bowel syndrome: can neuroimmune interactions explain symptoms? Am J Gastroenterol (2013) 108(7):1066-74. doi:10.1038/ajg.2013.120

4. Chang L. The role of stress on physiologic responses and clinical symptoms in irritable bowel syndrome. Gastroenterology (2011) 140(3):761-5. doi:10.1053/j.gastro.2011.01.032

5. Lovell RM, Ford AC. Global prevalence of and risk factors for irritable bowel syndrome: a meta-analysis. Clin Gastroenterol Hepatol (2012) 10(7):712-21e4. doi:10.1016/j.cgh.2012.02.029

6. El-Salhy M. Irritable bowel syndrome: diagnosis and pathogenesis. World J Gastroenterol (2012) 18(37):5151-63. doi:10.3748/wjg.v18.i37.5151

7. Muller PA, Koscso B, Rajani GM, Stevanovic K, Berres ML, Hashimoto D, et al. Crosstalk between muscularis macrophages and enteric neurons regulates gastrointestinal motility. Cell (2014) 158(5):1210. doi:10.1016/j. cell.2014.04.050

8. Ray K. IBS: mindful of probiotics for psychiatric comorbidities in IBS. Nat Rev Gastroenterol Hepatol (2017) 14(7):386-7. doi:10.1016/j.cell.2014.08.002

9. Saha L. Irritable bowel syndrome: pathogenesis, diagnosis, treatment, and evidence-based medicine. World J Gastroenterol (2014) 20(22):6759-73. doi:10.3748/wjg.v20.i22.6759

10. Barbara G, Stanghellini V, De Giorgio R, Cremon C, Cottrell GS, Santini D, et al. Activated mast cells in proximity to colonic nerves correlate with abdominal pain in irritable bowel syndrome. Gastroenterology (2004) 126(3):693-702. doi:10.1053/j.gastro.2003.11.055

11. Stengel A, Tache Y. Corticotropin-releasing factor signaling and visceral response to stress. Exp Biol Med (Maywood) (2010) 235(10):1168-78. doi:10.1258/ebm.2010.009347

\section{AUTHOR CONTRIBUTIONS}

MC and XC drafted the manuscript. XC and JD supervised the project and conceived of the student. JC contributed to discussions and revisions. ZM and YL contributed to figure, and table, and manuscript editing.

\section{ACKNOWLEDGMENTS}

We dedicate this mini-review to the memory of Ji-Zeng Du, our dear supervisor, who passed away on June 30, 2017 while this research was in progress and our friend and collaborator, John Coote, who passed away on Nov 27, 2018 before the submission of our mini-review. Ji Zeng Du contributed greatly in understanding the mechanism of brain-endocrine-immune network function during hypoxia.

\section{FUNDING}

This work was supported by the Ministry Science and Technology of China, National Basic Research Program (973) of China (grant number 2012CB518200 and grant number 2006CB504100) and the National Natural Science Foundation of China (grant number 81741120 , grant number 30393130, grant number 31171145, and grant number 31471140).

12. Chen XQ, Kong FP, Zhao Y, Du JZ. High-altitude hypoxia induces disorders of the brain-endocrine-immune network through activation of corticotropinreleasing factor and its type-1 receptors. Zhongguo Ying Yong Sheng Li Xue Za Zhi (2012) 28(6):481-7.

13. Kiank C, Tache Y, Larauche M. Stress-related modulation of inflammation in experimental models of bowel disease and post-infectious irritable bowel syndrome: role of corticotropin-releasing factor receptors. Brain Behav Immun (2010) 24(1):41-8. doi:10.1016/j.bbi.2009.08.006

14. Tache Y, Kiank C, Stengel A. A role for corticotropin-releasing factor in functional gastrointestinal disorders. Curr Gastroenterol Rep (2009) 11(4):270-7. doi:10.1007/s11894-009-0040-4

15. Smith F, Clark JE, Overman BL, Tozel CC, Huang JH, Rivier JE, et al. Early weaning stress impairs development of mucosal barrier function in the porcine intestine. Am J Physiol Gastrointest Liver Physiol (2010) 298(3):G352-63. doi:10.1152/ajpgi.00081.2009

16. Greenwood-Van Meerveld B, Johnson AC, Cochrane S, Schulkin J, Myers DA. Corticotropin-releasing factor 1 receptor-mediated mechanisms inhibit colonic hypersensitivity in rats. Neurogastroenterol Motil (2005) 17(3):415-22. doi:10.1111/j.1365-2982.2005.00648.x

17. Maillot C, Million M, Wei JY, Gauthier A, Tache Y. Peripheral corticotropinreleasing factor and stress-stimulated colonic motor activity involve type 1 receptor in rats. Gastroenterology (2000) 119(6):1569-79. doi:10.1053/gast. 2000.20251

18. Qin HY, Xiao HT, Wu JC, Berman BM, Sung JJ, Bian ZX. Key factors in developing the trinitrobenzene sulfonic acid-induced post-inflammatory irritable bowel syndrome model in rats. World J Gastroenterol (2012) 18(20):2481-92. doi:10.3748/wjg.v18.i20.2481

19. Mao Q, Shi L, Wang ZG, Luo YH, Wang YY, Li X, et al. Chemical profiles and pharmacological activities of Chang-Kang-Fang, a multi-herb Chinese medicinal formula, for treating irritable bowel syndrome. J Ethnopharmacol (2017) 201:123-35. doi:10.1016/j.jep.2017.02.045

20. Winston JH, Xu GY, Sarna SK. Adrenergic stimulation mediates visceral hypersensitivity to colorectal distension following heterotypic chronic stress. Gastroenterology (2010) 138(1):294-304e3. doi:10.1053/j.gastro.2009.09.054

21. Zou N, Lv H, Li J, Yang N, Xue H, Zhu J, et al. Changes in brain G proteins and colonic sympathetic neural signaling in chronic-acute combined stress 
rat model of irritable bowel syndrome (IBS). Transl Res (2008) 152(6):283-9. doi:10.1016/j.trsl.2008.10.002

22. Garabadu D, Shah A, Singh S, Krishnamurthy S. Protective effect of eugenol against restraint stress-induced gastrointestinal dysfunction: potential use in irritable bowel syndrome. Pharm Biol (2015) 53(7):968-74. doi:10.3109/ 13880209.2014.950674

23. Murakami T, Kamada K, Mizushima K, Higashimura Y, Katada K, Uchiyama K, et al. Changes in intestinal motility and gut microbiota composition in a rat stress model. Digestion (2017) 95(1):55-60. doi:10.1159/000452364

24. Chen A, Chen Y, Tang Y, Bao C, Cui Z, Xiao M, et al. Hippocampal AMPARs involve the central sensitization of rats with irritable bowel syndrome. Brain Behav (2017) 7(3):e00650. doi:10.1002/brb3.650

25. Fourie NH, Wang D, Abey SK, Creekmore AL, Hong S, Martin CG, et al. Structural and functional alterations in the colonic microbiome of the rat in a model of stress induced irritable bowel syndrome. Gut Microbes (2017) 8(1):33-45. doi:10.1080/19490976.2016.1273999

26. Funatsu T, Takeuchi A, Hirata T, Keto Y, Akuzawa S, Sasamata M. Effect of ramosetron on conditioned emotional stress-induced colonic dysfunction as a model of irritable bowel syndrome in rats. Eur J Pharmacol (2007) 573(1-3):190-5. doi:10.1016/j.ejphar.2007.06.041

27. Chen Y, Li Z, Yang Y, Lin L, Zhang H. Role of glucagon-like peptide-1 in the pathogenesis of experimental irritable bowel syndrome rat models. Int $\mathrm{J} \mathrm{Mol}$ Med (2013) 31(3):607-13. doi:10.3892/ijmm.2013.1252

28. Yoo BB, Mazmanian SK. The enteric network: interactions between the immune and nervous systems of the gut. Immunity (2017) 46(6):910-26. doi:10.1016/j.immuni.2017.05.011

29. Vanner S, Greenwood-Van Meerveld B, Mawe G, Shea-Donohue T, Verdu EF, Wood J, et al. Fundamentals of neurogastroenterology: basic science. Gastroenterology (2016) 150(6):1280-91. doi:10.1053/j.gastro.2016.02.018

30. Hu Y, Li M, Lu B, Wang X, Chen C, Zhang M. Corticotropin-releasing factor augments LPS-induced immune/inflammatory responses in JAWSII cells. Immunol Res (2016) 64(2):540-7. doi:10.1007/s12026-015-8740-3

31. Chatzaki E, Crowe PD, Wang L, Million M, Tache Y, Grigoriadis DE. CRF receptor type 1 and 2 expression and anatomical distribution in the rat colon. J Neurochem (2004) 90(2):309-16. doi:10.1111/j.1471-4159.2004.02490.x

32. Baker C, Richards LJ, Dayan CM, Jessop DS. Corticotropin-releasing hormone immunoreactivity in human $\mathrm{T}$ and $\mathrm{B}$ cells and macrophages: colocalization with arginine vasopressin. J Neuroendocrinol (2003) 15(11):1070-4. doi:10.1046/j.1365-2826.2003.01099.x

33. Kravchenco IV, Furalev VA. Secretion of immunoreactive corticotropin releasing factor and adrenocorticotropic hormone by T- and B-lymphocytes in response to cellular stress factors. Biochem Biophys Res Commun (1994) 204(2):828-34. doi:10.1006/bbrc.1994.2534

34. Stephanou A, Jessop DS, Knight RA, Lightman SL. Corticotrophin-releasing factor-like immunoreactivity and mRNA in human leukocytes. Brain Behav Immun (1990) 4(1):67-73. doi:10.1016/0889-1591(90)90007-D

35. Saruta M, Takahashi K, Suzuki T, Torii A, Kawakami M, Sasano H. Urocortin 1 in colonic mucosa in patients with ulcerative colitis. J Clin Endocrinol Metab (2004) 89(11):5352-61. doi:10.1210/jc.2004-0195

36. Hojo M, Ohkusa T, Tomeoku H, Koido S, Asaoka D, Nagahara A, et al. Corticotropin-releasing factor secretion from dendritic cells stimulated by commensal bacteria. World J Gastroenterol (2011) 17(35):4017-22. doi:10.3748/wjg.v17.i35.4017

37. Koido S, Ohkusa T, Kan S, Takakura K, Saito K, Komita H, et al. Production of corticotropin-releasing factor and urocortin from human monocytederived dendritic cells is stimulated by commensal bacteria in intestine. World J Gastroenterol (2014) 20(39):14420-9. doi:10.3748/wjg.v20.i39.14420

38. Meng L, Lu Z, Xiaoteng W, Yue H, Bin L, Lina M, et al. Corticotropin-releasing factor changes the phenotype and function of dendritic cells in mouse mesenteric lymph nodes. J Neurogastroenterol Motil (2015) 21(4):571-80. doi:10.5056/jnm15019

39. Kawahito Y, Sano H, Mukai S, Asai K, Kimura S, Yamamura Y, et al. Corticotropin releasing hormone in colonic mucosa in patients with ulcerative colitis. Gut (1995) 37(4):544-51. doi:10.1136/gut.37.4.544

40. Yuan PQ, Wu SV, Wang L, Tache Y. Corticotropin releasing factor in the rat colon: expression, localization and upregulation by endotoxin. Peptides (2010) 31(2):322-31. doi:10.1016/j.peptides.2009.11.012

41. Kawahito Y, Sano H, Kawata M, Yuri K, Mukai S, Yamamura Y, et al. Local secretion of corticotropin-releasing hormone by enterochromaffin cells in human colon. Gastroenterology (1994) 106(4):859-65. doi:10.1016/0016-5085 (94) $90743-9$

42. Yuan PQ, Wu SV, Elliott J, Anton PA, Chatzaki E, Million M, et al. Expression of corticotropin releasing factor receptor type $1(\mathrm{CRF} 1)$ in the human gastrointestinal tract and upregulation in the colonic mucosa in patients with ulcerative colitis. Peptides (2012) 38(1):62-9. doi:10.1016/j.peptides.2012. 07.028

43. Barreau F, Cartier C, Leveque M, Ferrier L, Moriez R, Laroute V, et al. Pathways involved in gut mucosal barrier dysfunction induced in adult rats by maternal deprivation: corticotrophin-releasing factor and nerve growth factor interplay. J Physiol (2007) 580(Pt 1):347-56. doi:10.1113/jphysiol.2006.120907

44. Chatzaki E, Anton PA, Million M, Lambropoulou M, Constantinidis T, Kolios G, et al. Corticotropin-releasing factor receptor subtype 2 in human colonic mucosa: down-regulation in ulcerative colitis. World J Gastroenterol (2013) 19(9):1416-23. doi:10.3748/wjg.v19.19.1416

45. Chang J, Hoy JJ, Idumalla PS, Clifton MS, Pecoraro NC, Bhargava A Urocortin 2 expression in the rat gastrointestinal tract under basal conditions and in chemical colitis. Peptides (2007) 28(7):1453-60. doi:10.1016/j. peptides.2007.05.008

46. Tsatsanis C, Androulidaki A, Dermitzaki E, Gravanis A, Margioris AN Corticotropin releasing factor receptor 1 (CRF1) and CRF2 agonists exert an anti-inflammatory effect during the early phase of inflammation suppressing LPS-induced TNF-alpha release from macrophages via induction of COX-2 and PGE2. J Cell Physiol (2007) 210(3):774-83. doi:10.1002/ jcp. 20900

47. Tsatsanis C, Androulidaki A, Alissafi T, Charalampopoulos I, Dermitzaki E, Roger $\mathrm{T}$, et al. Corticotropin-releasing factor and the urocortins induce the expression of TLR 4 in macrophages via activation of the transcription factors PU.1 and AP-1. JImmunol (2006) 176(3):1869-77. doi:10.4049/jimmunol. 176.3.1869

48. Smith EM, Gregg M, Hashemi F, Schott L, Hughes TK. Corticotropin releasing factor (CRF) activation of NF-kappaB-directed transcription in leukocytes. Cell Mol Neurobiol (2006) 26(4-6):1021-36. doi:10.1007/s10571006-9040-1

49. Kempuraj D, Papadopoulou NG, Lytinas M, Huang M, Kandere-Grzybowska K, Madhappan B, et al. Corticotropin-releasing hormone and its structurally related urocortin are synthesized and secreted by human mast cells. Endocrinology (2004) 145(1):43-8. doi:10.1210/en.2003-0805

50. Wallon C, Yang PC, Keita AV, Ericson AC, McKay DM, Sherman PM, et al. Corticotropin-releasing hormone (CRH) regulates macromolecular permeability via mast cells in normal human colonic biopsies in vitro. Gut (2008) 57(1):50-8. doi:10.1136/gut.2006.117549

51. Yuan PQ, Million M, Wu SV, Rivier J, Tache Y. Peripheral corticotropin releasing factor (CRF) and a novel CRF1 receptor agonist, stressin1-A activate CRF1 receptor expressing cholinergic and nitrergic myenteric neurons selectively in the colon of conscious rats. Neurogastroenterol Motil (2007) 19(11):923-36. doi:10.1111/j.1365-2982.2007.00978.x

52. Liu S, Gao N, Hu HZ, Wang X, Wang GD, Fang X, et al. Distribution and chemical coding of corticotropin-releasing factor-immunoreactive neurons in the guinea pig enteric nervous system. J Comp Neurol (2006) 494(1):63-74. doi:10.1002/cne.20781

53. Ekman R, Servenius B, Castro MG, Lowry PJ, Cederlund AS, Bergman O, et al. Biosynthesis of corticotropin-releasing hormone in human T-lymphocytes. J Neuroimmunol (1993) 44(1):7-13. doi:10.1016/0165-5728(93)90262-W

54. Muglia LJ, Jenkins NA, Gilbert DJ, Copeland NG, Majzoub JA. Expression of the mouse corticotropin-releasing hormone gene in vivo and targeted inactivation in embryonic stem cells. J Clin Invest (1994) 93(5):2066-72. doi:10.1172/JCI117201

55. la Fleur SE, Wick EC, Idumalla PS, Grady EF, Bhargava A. Role of peripheral corticotropin-releasing factor and urocortin II in intestinal inflammation and motility in terminal ileum. Proc Natl Acad Sci U S A (2005) 102(21):7647-52. doi:10.1073/pnas.0408531102

56. Zhang L, Song J, Bai T, Qian W, Hou XH. Stress induces more serious barrier dysfunction in follicle-associated epithelium than villus epithelium involving mast cells and protease-activated receptor-2. Sci Rep (2017) 7(1):4950. doi:10.1038/s41598-017-05064-y

57. Yu Y, Liu ZQ, Liu XY, Yang L, Geng XR, Yang G, et al. Stress-derived corticotropin releasing factor breaches epithelial endotoxin tolerance. PLoS One (2013) 8(6):e65760. doi:10.1371/journal.pone.0065760 
58. Jizhong S, Qiaomin W, Chao W, Yanqing L. Corticotropin-releasing factor and toll-like receptor gene expression is associated with low-grade inflammation in irritable bowel syndrome patients with depression. Gastroenterol Res Pract (2016) 2016:7394924. doi:10.1155/2016/7394924

59. Santos J, Yates D, Guilarte M, Vicario M, Alonso C, Perdue MH. Stress neuropeptides evoke epithelial responses via mast cell activation in the rat colon. Psychoneuroendocrinology (2008) 33(9):1248-56. doi:10.1016/j. psyneuen.2008.07.002

60. Hoffman JM, Baritaki S, Ruiz JJ, Sideri A, Pothoulakis C. Corticotropinreleasing hormone receptor 2 signaling promotes mucosal repair responses after colitis. Am J Pathol (2016) 186(1):134-44. doi:10.1016/j.ajpath.2015.09.013

61. Long Y, Wang W, Wang H, Hao L, Qian W, Hou X. Characteristics of intestinal lamina propria dendritic cells in a mouse model of postinfectious irritable bowel syndrome. J Gastroenterol Hepatol (2012) 27(5):935-44. doi:10.1111/j.1440-1746.2011.07046.x

62. Zhuang Z, Zhang L, Wang X, Tao L, Lv B. PDIA3 gene induces visceral hypersensitivity in rats with irritable bowel syndrome through the dendritic cell-mediated activation of T cells. PeerJ (2016) 4:e2644. doi:10.7717/ peerj. 2644

63. Spiller RC, Jenkins D, Thornley JP, Hebden JM, Wright T, Skinner M, et al. Increased rectal mucosal enteroendocrine cells, T lymphocytes, and increased gut permeability following acute Campylobacter enteritis and in post-dysenteric irritable bowel syndrome. Gut (2000) 47(6):804-11. doi:10.1136/gut.47. 6.804

64. Overman EL, Rivier JE, Moeser AJ. CRF induces intestinal epithelial barrier injury via the release of mast cell proteases and TNF-alpha. PLoS One (2012) 7(6):e39935. doi:10.1371/journal.pone.0039935

65. Li Y, Song Z, Kerr KA, Moeser AJ. Chronic social stress in pigs impairs intestinal barrier and nutrient transporter function, and alters neuroimmune mediator and receptor expression. PLoS One (2017) 12(2):e0171617. doi:10.1371/journal.pone.0171617
66. Gue M, Del Rio-Lacheze C, Eutamene H, Theodorou V, Fioramonti J, Bueno L. Stress-induced visceral hypersensitivity to rectal distension in rats: role of CRF and mast cells. Neurogastroenterol Motil (1997) 9(4):271-9. doi:10.1046/j.1365-2982

67. Dunlop SP, Jenkins D, Spiller RC. Distinctive clinical, psychological, and histological features of postinfective irritable bowel syndrome. Am J Gastroenterol (2003) 98(7):1578-83. doi:10.1111/j.1572-0241.2003.07542.x

68. Vermillion DL, Ernst PB, Collins SM. T-lymphocyte modulation of intestinal muscle function in the Trichinella-infected rat. Gastroenterology (1991) 101(1):31-8. doi:10.1016/0016-5085(91)90456-U

69. Ohman L, Lindmark AC, Isaksson S, Posserud I, Strid H, Sjovall H, et al. B-cell activation in patients with irritable bowel syndrome (IBS). Neurogastroenterol Motil (2009) 21(6):644-50, e27. doi:10.1111/j.1365-2982.2009.01272.x

70. Forshammar J, Isaksson S, Strid H, Stotzer PO, Sjovall H, Simren M, et al. A pilot study of colonic B cell pattern in irritable bowel syndrome. Scand J Gastroenterol (2008) 43(12):1461-6. doi:10.1080/00365520802272126

71. Vicario M, Gonzalez-Castro AM, Martinez C, Lobo B, Pigrau M, Guilarte M, et al. Increased humoral immunity in the jejunum of diarrhoea-predominant irritable bowel syndrome associated with clinical manifestations. Gut (2015) 64(9):1379-88. doi:10.1136/gutjnl-2013-306236

Conflict of Interest Statement: The authors declare that the research was conducted in the absence of any commercial or financial relationships that could be construed as a potential conflict of interest.

Copyright (c) 2018 Chatoo, Li, Ma, Coote, Du and Chen. This is an open-access article distributed under the terms of the Creative Commons Attribution License (CC BY). The use, distribution or reproduction in other forums is permitted, provided the original author(s) and the copyright owner are credited and that the original publication in this journal is cited, in accordance with accepted academic practice. No use, distribution or reproduction is permitted which does not comply with these terms. 